\title{
Disharmoni dalam Dinamika Penyelenggaraan Pemerintahan Daerah
}

\author{
Dikson Junus \\ Sucipto Potabuga \\ Program Studi Ilmu Pemerintahan, Universitas Gorontalo \\ diksonjunus@gmail.com
}

\begin{abstract}
The dynamics of good governance at the central government level to the level of local government is inseparable from the conflict. Conflict usually occurs horizontally or vertically, causing disharmony in the administration. In the period 2014-2015 in the Province of Gorontalo had experienced dynamics in governance that led to poor inter-regional relations. This paper will discuss the disharmony of Governor and Mayor relationship with the focus of discussion on the function of coordination and supervision in the implementation of local government. The results show that the disinclination of government relations between provinces and municipalities due to unclear division of authority between governments so that structural and functional coordination is not effective and achievement of goals does not always work as expected. This research suggests changing the mindset of government apparatus in the management and administration of government and strengthening cooperation among local government, so that the dynamics of governance can run effectively and efficiently.
\end{abstract}

Keywords: local govenrment; government relations; Gorontalo.

\section{ABSTRAK}

Dinamika tata pemerintahan yang baik di tingkat pemerintah pusat hingga tingkat pemerintah daerah tidak dapat dipisahkan dari konflik. Konflik biasanya terjadi secara horizontal atau vertikal, menyebabkan ketidakharmonisan dalam administrasi. Pada periode 2014-2015 di Provinsi Gorontalo telah mengalami dinamika dalam pemerintahan yang menyebabkan hubungan antar daerah yang buruk. Tulisan ini akan membahas ketidakharmonisan hubungan Gubernur dan Walikota dengan fokus diskusi pada fungsi koordinasi dan pengawasan dalam pelaksanaan pemerintah daerah. Hasilnya menunjukkan bahwa disinslinasi hubungan pemerintah antara provinsi dan kota karena pembagian wewenang yang tidak jelas antara pemerintah sehingga koordinasi struktural dan fungsional tidak efektif dan pencapaian tujuan tidak selalu berjalan seperti yang diharapkan. Penelitian ini menyarankan untuk mengubah pola pikir aparatur pemerintah dalam manajemen dan administrasi pemerintah dan memperkuat kerja sama antar pemerintah daerah, sehingga dinamika pemerintahan dapat berjalan efektif dan efisien.

Kata Kunci: penerintahan lokal; hubungan pemerintah; Gorontalo. 


\section{PENDAHULUAN}

Tujuan dibentuknya pemerintah daerah baik Propinsi maupun Kabupaten/Kota adalah untuk mewujudakn efektivitas dan efisiensi pelaksanaan kepemerintah- an, oleh karenanya baik Undang-Undang Nomor 22 tahun 1999, Undang-Undang Nomor 32 tahun 2004 maupun 23 Tahun 2014 sebagaimana telah diubah dengan Undang-Undang Nomor 2 Tahun 2015 Tentang Pemerintahan Daerah menegaskan bahwa titik tumpu pelaksanaan azas desentralisasi pada daerah Kabupaten/Kota. Hal ini sebagaima termuat dalam pasal 18 ayat (1) Undang-Undang Dasar 1945 bahwa "Negara kesatuan Republik Indonesia dibagi atas daerah-daerah propinsi, dan daerah propinsi dibagi atas Kabupaten/ kota yang tiap-tiap propinsi, Kabupaten/ Kota mempunyai pemerintahan daerah yang diatur undang-undang.

Dinamika hubungan pemerintah Propinsi dengan Pemerintah Kabupaten/Kota di Propinsi Gorontalo antara lain meliputi :

1. Maksimalisasi fungsi koordinasi penyelenggaraan pemerintahan daerah baik pemerintah daerah propinsi maupun kabupaten / kota,

2. Efektifitas pembinaan dan pengawasan penyelenggaraan Pemerintahan Daerah

Menurut PP No. 19 tahun 2010 dalam menjalankan fungsi koordinasi, Pemerintah Propinsi Gorontalo memiliki tugas untuk melakukan koordinasi penyelenggaraan pemerintahan antara pemerintah daerah propinsi dengan instansi vertikal, dan antar instansi vertikal di wilayah propinsi yang bersangkutan, koordinasi penyelenggara- an pemerintahan antar pemerintah propinsi dengan pemerintah kabupaten/ kota di wilayah propinsi yang bersangkutan dan koordinasi penyelenggaraan pemerintahan antar pemerintahan daerah kabupaten/ kota di wilayah propinsi yang bersangkutan. Selain itu juga, Gubernur memiliki kewenangan untuk melakukan pengawasan kinerja pemerintah Kabupaten/Kota di seluruh wilayah Provinsi Gorontalo sebagimana diamanatkan oleh peraturan tersebut.

Penelitian ini bertujuan untuk mengetahui disharmoni dalam dinamika penyelenggaraan pemerintahan daerah di Propinsi Gorontalo dengan fokus pada aspek koordinasi dan pengawasan dalam penyelengaraan pemerintahan antar pemerintah Propinsi dengan pemerintah Kabupaten/Kota di wilayah Propinsi Gorontalo.

\section{KAJIAN TEORI}

\subsection{Penyelenggaraan Pemerintah Daerah}

Konsep pemerintahan daerah dalam UU No. 32 Tahun 2004 (Pasal 1 Ayat 2), menyebtukan bahwa pemerintahan daerah adalah penyelenggaraan urusan pemerintahan oleh pemerintah daerah dan DPRD menurut asas otonomi dan tugas pembantuan dengan prinsip otonomi seluas-luasnya dalam sistem dan prinsip Negara Kesatuan Republik Indonesia sebagaimana dimaksud dalam Undang-Undang Dasar Negara Republik Indonesia Tahun 1945.

Pemerintah daerah adalah Gubernur, Bupati, atau Walikota, dan perangkat daerah sebagai unsur penyelenggara pemerintahan daerah (Pasal 1 Ayat 3). Dewan Perwakilan Rakyat Daerah yang selanjutnya disebut DPRD adalah lembaga perwakilan rakyat daerah sebagai unsur penyelenggara pemerintahan daerah (Pasal 1 Ayat 4). Pemerintahan daerah sebagaimana dimaksud pada ayat (1) mengatur dan mengurus sendiri urusan pemerintahan menurut asas otonomi 
dan tugas pembatuan (Pasal 2 Ayat 2). Pemerintahan daerah sebagaimana dimaksud pada ayat (2) menjalankan otonomi seluas-luasnya, kecuali urusan pemerintahan yang menjadi urusan Pemerintah, dengan tujuan meningkatkan kesejahteraan masyarakat, pelayanan umum, dan daya saing daerah (Pasal 2 Ayat 3). Pemerintahan daerah dalam menyelenggarakan urusan pemerintahan memiliki hubungan dengan Pemerintah dan dengan pemerintahan daerah lainnya (Pasal 2 Ayat 4). Hubungan sebagaimana dimaksud pada ayat (4) meliputi hubungan wewenang, keuangan, pelayanan umum, pemanfaatan sumber daya alam, dan sumber daya lainnya (Pasal 2 Ayat 5). Hubungan keuangan, pelayanan umum, pemanfaatan sumber daya alam, dan sumber daya lainnya dilaksanakan secara adil dan selaras (Pasal 2 Ayat 6). Hubungan wewenang, keuangan, pelayanan umum, pemanfaatan sumber daya alam dan sumber daya lainnya menimbulkan hubungan administrasi dan kewilayahan antar susunan pemerintahan (Pasal 2 Ayat 7).

\subsection{Koordinasi}

Secara normatif, koordinasi diartikan sebagai kewenangan untuk menggerakkan, menyerasikan, menyelaraskan, dan menyeimbangkan kegiatankegiatan yang spesifik atau berbeda-beda agar semuanya terarah pada tujuan tertentu. Sedangkan secara fungsional, koordinasi dilakukan guna untuk mengurangi dampak negatif spesialisasi dan mengefektifkan pembagian kerja (Ndraha, 2003:290).

Sedangkan fungsi koordinasi Menurut Handayaningrat (1989:119-121) menjelaskan fungsi koordinasi adalah sebagai berikut :

a. Sebagai salah satu fungsi manajemen, disamping adanya fungsi perencanaan, penyusunan pegawai, pembinaan kerja, motivasi dan pengawasan. Dengan kata lain koordinasi adalah fungsi organik dari pimpinan.

b. Untuk menjamin kelancaran mekanisme prosedur kerja dari berbagai komponen dalam organisasi. Kelancaran mekanisme prosedur kerja harus dapat terjamin dalam rangka pencapaian tujuan organisasi dengan menghindari eminimal mungkin perselisihan yang timbul antara sesama komponen organisasi dan mengusahakan semaksimal mungkin kerjasama di antara komponen-komponen tersebut.

c. Sebagai usaha yang mengarahkan dan menyatukan kegiatan yang mengandung makna adanya keterpaduan (integrasi) yang dilakukan secara serasi dan simultan/singkronisasi dari seluruh tindakan yang dijalankan oleh organisasi, sehingga organisasi bergerak sebagai kesatuan yang bulat guna melaksanakan seluruh tugas organisasi yang diperlukan untuk mencapai tujuannya. Hal itu sesuai dengan prinsip koordinasi, integrasi, dan singkronisasi.

d. Sebagai faktor dominan dalam kelangsungan hidup suatu organisasi pada tingkat tertentu dan ditentukan oleh kualitas usaha koordinasi yang dijalankan. Peningkatan kualitas koordinasi merupakan usaha yang perlu dilakukan secara terus menerus karena tidak hanya masalah teknis semata tetapi tergantung dari sikap, tindakan, dan langkah dari pemegang fungsi organik dari pimpinan.

e. Untuk melahirkan jaringan hubungan kerja atau komunikasi. Jaringan hubungan kerja tersebut berbentuk saluran hubungan kerja yang 
membutuhkan berbagai pusat pengambilan keputusan dalam organisasi. Hubungan kerja ini perlu dipelihara agar terhindar dari berbagai rintangan yang akan membawa organisasi ke situasi yang tidak berfungsi sehingga tidak berjalan secara efektif dan efisien.

f. Sebagai usaha untuk menyelaraskan setiap tindakan, langkah dan sikap yang terpadu dari para pejabat pengambil keputusan dan para pelaksana. Dalam organisasi yang besar dan kompleks, pertumbuhan organisasi akan menyembabkan penambahan beban kerja, penambahan fungsi-fungsi yang harus dilaksanakan dan penambahan jabatan yang perlu di koordinasikan.

g. Untuk penataan spesialisasi dalam berbagai keanekaragaman tugas. Karena timbulnya spesialisasi yang semakin tajam merupakan konsekuensi logis dari perkembangan ilmu pengetahuan dan teknologi.

\section{Pengawasan}

Pengawasan merupakan usaha agar pencapaian tujuan organisasi tepat rencana yang telah ditargetkan. Definisi pengawasan menurut Siagian (2011: 319) sebagai berikut :"Pengawasan adalah segenap kegiatan untuk menyakinkan dan menjamin bahwa pekerjaan-pekerjaan dilakukan sesuai dengan rencana yang telah ditentukan, kebijakan-kebijakan yang telah digariskan, dan perintahperintah yang telah diberikan dalam rangka pelaksanaan kerja untuk mencapai target yang telah ditentukan".

Tentang pengawasan hubungannya dengan penyelenggaraan Pemerintahan Daerah pada bahwa pengawasan adalah segala usaha atau kegiatan untuk mengetahui menilai kenyataan yang sebenarnya mengenai pelaksanaan tugas atau kegiatan/ apakah sesuai dengan yang semestinya atau tidak. Dengan demikian manifestasi dari kinerja pengawasan adalah kegiatan untuk menilai suatu pelaksanaan tugas secara de facto, sedangkan tujuan pengawasan itu pada hakekatnya adalah sebagai media terbatas untuk melakukan semacam cross check atau, pencocokan apakah kegiatan yang dilaksanakan telah sesuai dengan tolak ukur yang telah ditentukan sebelumnya atau tidak. Demikian pula bagaimana dengan tindaklanjut dari hasil pengawasan tersebut. (Sukiansyah dalam Amalia, 2010:37).

\section{METODE PENELITIAN}

\subsection{Jenis Penelitian}

Jenis penelitian ini adalah penelitian deskriptif dengan menggunakan pendekatan kualitatif. Penelitian ini menggunakan analisis institusionalisme karena penelitian ini dilakukan pada suatu bagian organisasi pemerintahan. Pierson \& Skocpol (2008), menyatakan bahwa analisis institusional digunakan untuk mengkaji segala sesuatu dari proses legislatif, efek terhadap gerakan sosial, sampai politik hukum.

\subsection{Lokasi Penelitian}

Penelitian dilaksanakan di Provinsi Gorontalo dengan melihat harmonisasi hubungan pemerintahan daerah. Penelitian akan memfokuskan pada pengamatan mengenai proses kemunikasi antar pemerintah dalam lingkup Provinsi Gorontalo dalam rangka penyelenggaraan pemerintahan dan pemberian pelayanan kepada masyarakat. 


\subsection{Pengumpulan Data}

Teknik pengumpulan data yang digunakan dalam penelitian yaitu dengan menggunakan wawancara mendalam, dan dokumentasi. Wawancara mendalam (Indepth Interview), yaitu teknik pengumpulan data dimana peneliti secara langsung mengadakan tanya jawab dengan pemerintah daerah Provinsi Gorontalo. Dokumentasi, yaitu teknik pengumpulan data yang dilakukan untuk mendokumentasikan semua data dan informasi yang diperoleh di pemrintah Provinsi Gorontalo baik yang diperoleh secara langsung maupun melalui media internet.

\subsection{Analisis Data}

Menurut Norman (2009), kegiatan analisis data kualitatif mencakup pengujian, mengerutkan, mengkategorikan, mengevaluasi, membandingkan, mensintesiskan dan mengkontemplasikan data yang dikode seperti halnya interview data mentah dan data yang direkam. analisis data yang dilakukan dalam penelitian ini melalui analisis kualitatif dengan tahapan pengelolaan data yaitu penafsiran data, reduksi data, penyusunan data, pemeriksaan keabsahan data, dan menarik kesimpulan.

\section{HASIL PENELITIAN DAN PEMBAHASAN}

\subsection{Disharmoni dalam Koordinasi}

Menurut PP No. 19 tahun 2010 dalam menjalankan fungsi koordinasi, Pemerintah Provinsi Gorontalo memiliki tugas untuk melakukan koordinasi penyelenggaraan pemerintahan antara pemerintah daerah provinsi dengan instansi vertikal, dan antar instansi vertikal di wilayah provinsi yang bersangkutan, koordinasi penyelenggara- an pemerintahan antara pemerintah daerah provinsi dengan pemerintah daerah kabupaten/kota di wilayah provinsi yang bersangkutan dan koordinasi penyelenggaraan pemerintah- an antar pemerintahan daerah kabupaten/ kota di wilayah provinsi yang bersangkutan.

Hasil penelitian yang dilakukan pada tahun 2014-2015 dinamika penyelenggaraan pemerintahan daerah di Propinsi Gorontalo menunjukkan bahwa setiap kali Pemerintah Propinsi dalam hal ini Gubernur Rusli Habibie hendak ingin menjalankan fungsi koordinasi selalu tidak berjalan dengan maksimal disebabkan oleh tidak adanya keinginan dari pemerintah Kota Gorontalo dalam hal ini Walikota Adhan Dambea untuk menghadiri rapat koordinasi yang dibangun oleh pemerintah Propinsi. Keadaan ini berbeda dengan pemerintah Kabupaten lainnya yang ada di wilayah Propinsi Gorontalo, dimana dalam setiap penyelenggaraan rapat koordinasi dengan pemerintah propinsi turut menghadiri rapat koordinasi Pemerintahan yang dilaksanakan oleh Pemerintah Propinsi Gorontalo.

Dinamika koordinasi dalam penyelenggaraan pemerintahan yang terjadi menunjukkan adanya disharmoni antara Gubernur dengan Walikota. Disharmoni ini terjadi karena Walikota mengannggap sebagai kepala daerah mempunyai kewenangan untuk menyelenggarakan pemerintahan dan merasa tidak berkewajiban untuk melakukan koordinasi dengan Gubernur. Ketidakharmonisan hubungan pemerintah propinsi dengan pemerintah kabupaten di Gorontalo pernah terjadi pada masa kepemimpinan Fadhel Mohamad sebagai Gubernur dan Ahmad Pakaya sebagai Bupati Gorontalo. 
Ketidakharmonisan hubungan antara pemerintah propinsi dengan kabupaten/kota sebenarnya telah lama dirasakan sejak berlakukannya undangundang tentang pemerintahan daerah pada masa pemerintahan orde baru. Hal ini disebabkan pertama; ketidakseimbangan kewenangan antar pemerintah pusat, propinsi dan kabupaten/kota. Kedua ketidakjelasan batas-batas kewenangan, sehingga terjadi rebutan atau saling mengklaim terhadap kewenangan tersebut. Bupati maupun Walikota menganggap Gubernur bukanlah atasan langsung dalam struktur organisasi pemerintahan sehingga tidak berkewajiban untuk melakukan koordinasi dalam penyelenggaraan pemerintahan di daerah.

Desentralisasi dalam penyelenggaraan pemerintahan oleh pemerintah daerah sangat berlebihan bahkan disalahartikan sebagian besar pemerintah daerah. Pemerintah daerah menganggap bahwa kewenangannya sangat besar karena memiliki wilayah kekuasaan yang jelas. Sehingga daerah beranggapan bahwa otoritas penguasaan terhadap seluruh potensi yang ada di wilayahnya adalah kewenangannya secara keseluruhan. Dan secara politik Bupati/Walikota dipilih oleh rakyatnya dan bertanggungjawab terhadap rakyatnya juga.

Fenomena ini telah menunjukan sebuah keadaan dimana telah terjadi relasi yang disharmoni antar pemerintah kabupaten/kota dengan pemerintah propinsi, termasuk pemerintah provinsi maupun pemerintah pusat. Bahwa fungsi koordinasi pemerintah Propinsi dengan pemerintah Kabupaten/Kota bermasalah menyebabkan kurang efektifnya pelaksanaan koordinasi yang diperlukan, sehingga pencapaian sasaran/tujuan tidak selalu berjalan sebagaimana yang diharapkan.

Berdasarkan fenomena bahwa fungsi koordinasi kurang efektif, terjadi ditingkat kelembagaan acapkali terjadi hubungan yang kurang baik antara pemerintah propinsi dan pemerintah kabupaten disaat pihak pemerintah propinsi akan melakukan koordinasi yang diakibatkan oleh adanya variasi nomenklatur kelembagaan yang berbeda baik antara propinsi dengan kabupaten atau antar kabupaten. Perbedaan nomenklatur ini berimplikasi pada disharmoni koordinasi dan pelaksanaan tugas yang bersifat lintas kabupaten. Contohnya di tingkat pemerintah propinsi memiliki dinas yang menangani persoalan lingkungan hidup (Dinas LH), ketika pemerintah propinsi meminta bantuan untuk implementasi urusan lingungan hidup di tingkat kabupaten sering terjadi hambatan, sebab di tingkat kabupaten tidak ada dinas tersebut, hanya ada bagian yang tentunya kewenangannya terbatas.

Regulasi yang mengatur tentang organisasi pemerintah daerah secara spesifik belum mengatur keseragaman atau kesamaan organisasi pemerintah daerah (OPD) secara struktural dari pemerintah propinsi dan kabupaten/kota. Demikian halnya secara fungsional bahwa Bupati/Walikota dan Gubernur adalah pejabat politik sehingga hubungan keduanya secara struktual tidak saling tersubordinasi. Demikian halnya pada level pimpinan OPD, masingmasing pimpinan bertanggungjawab pada kepala daerahnya. Artainya bahwa pemerintah propinsi bukan atasan langsung dari pemerintah kabupaten/kota. Keadaan ini dapat menimbulkan koordinasi kurang efektif dan akan menjadi hambatan dalam pelaksanaan koordinasi antara pemerintah propinsi dengan pemerintah kabupaten/kota.

Kurang efektifnya koordinasi kedua Kepala Daerah ini disebabkan adanya hambatan hambatan dalam koordinasi baik vertikal maupun fungsional. Hal ini 
sejalan dengan pendapat Handayaningrat (1989:129) yang mengatakan bahwa faktor penghambat dalam koordinasi sebagai berikut :

a. Hambatan-hambatan dalam koordinasi vertikal (struktural).

Dalam koordinasi vertikal (struktural) sering terjadi hambatan-hambatan disebabkan perumusan tugas, wewenang dan tanggung jawab tiap-tiap satuan kerja (unit kerja) kurang jelas. Disamping itu adanya hubungan dan tata kerja serta prosedur kurang dipahami oleh pihak-pihak yang bersangkutan dan kadang-kadang timbul keragu-raguan diantara mereka. Sebenarnya hambatan-hambatan yang demikian itu tidak perlu karena antara yang mengkoordinasikan dan yang dikoordinasikan ada hubungan komando dalam susunan organisasi yang bersifat hierarkis.

b. Hambatan-hambatan dalam koordinasi fungsional

Hambatan-hambatanyang timbul pada koordinasi fungsional baik yang horizontal maupun diagonal disebabkan karena antara yang mengkoordinasikan dengan yang dikoordinasikan tidak terdapat hubungan hierarkis (garis komando). Sedangkan hubungan keduanya terjadi karena adanya kaitan bahkan interdepedensi atas fungsi masing-masing. Adapun hal-hal yang biasanya menjadi hambatan dalam pelaksanaan koordinasi antara lain: 1) Para pejabat sering kurang menyadari bahwa tugas yang dilaksanakannya hanyalah merupakan sebagian saja dari keseluruhan tugas dalam organisasi untuk mencapai tujuan organisasi tersebut. 2) Para pejabat sering memandang tugasnya sendiri sebagai tugas yang paling penting dibandingkan dengan tugas-tugas lain. 3) Adanya pembagian kerja atau spesialisasi yang berlebihan dalam organisasi. 4) Kurang jelasnya rumusan tugas atau fungsi, wewenang dan tanggung jawab dari masingmasing pejabat atau satuan organisasi. 5) Adanya prosedur dan tata kerja yang kurang jelas dan berbelit-belit dan tidak diketahui oleh semua pihak yang bersangkutan dalam usaha kerjasama. 6) Kurangnya kemampuan dari pimpinan untuk menjalankan koordinasi yang disebabkan oleh kurangnya kecakapan, wewenang dan kewibawaan. 7) Tidak atau kurangnya forum komunikasi diantara para pejabat yang bersangkutan yang dapat dilakukan dengan saling tukar menukar informasi dan diciptakan adanya saling pengertian guna kelancaran pelaksanaan kerjasama.

\subsection{Disharmoni dalam Pengawasan}

Penyelenggaraan pemerintahan daerah di Propinsi Gorontalo, Gubernur memiliki kewenangan untuk melakukan pengawasan kinerja Pemerintah Kabupaten/Kota di seluruh wilayah Propinsi Gorontalo sebagimana diamanatkan oleh PP No. 19 tahun 2010. Gubernur selaku wakil pemerintah pusat di daerah melakukan pembinaan pengelolaan keuangan daerah kepada kabupaten/kota di wilayahnya, dan pembinaan ini tidak boleh bertentangan dengan pembinaan yang dilakukan oleh Menteri Dalam Negeri.

Contohnya dalam hal pengawasan pengelolaan keuangan daerah, untuk menjamin pencapaian sasaran yang telah ditetapkan, DPRD melakukan pengawasan atas pelaksanaan APBD yang bukan bersifat pemeriksaan. Untuk menjamin efisiensi dan efektivitas dalam pengelolaan keuangan daerah, kepala daerah mengangkat pejabat yang bertugas melakukan pengawasan internal pengelolaan keuangan daerah. Pengawasan internal ini mencakup seluruh aspek 
keuangan daerah termasuk pengawasan terhadap tata laksana penyelenggaraan program, kegiatan, dan manajemen pemerintah daerah yang melaporkan hasil pengawasannya kepada kapala daerah.

Dalam hal pengawasan terhadap rancangan peraturan daerah, menurut Amalia, D (2010:37) pemerintah dapat melakukan dua cara dalam penawasan: Pertama pengawasan terhadap rancangan peraturan daerah, yaitu terhadap rancangan peraturan daerah yang mengatur pajak daerah, retribusi daerah, APBD, dan RUTR, sebelum disahkan oleh kepala daerah terlebih dahulu dievaluasi oleh Menteri Dalam Negeri untuk ranperda Propinsi, dan oleh Gubernur terhadap raperda kabupaten/kota. Mekanisme ini dilakukan agar pengaturan tentang hal-hal tersebut dapat mencapai daya guna dan hasil guna yang optimal. Kedua pengawasan terhadap semua peraturan daerah di luar yang termuat di atas, yaitu setiap peraturan daerah wajib disampaikan kepada Menteri Dalam Negeri untuk pemerintah propinsi dan Gubernur untuk pemerintah kabupaten/kota. Hal ini untuk memperoleh klarifikasi, terhadap peraturan daerah yang bertentangan dengan kepentingan umum dan peraturan yang lebih tinggi dapat dibatalkan sesuai mekanisme yang berlaku. Dalam rangka mengoptimalkan fungsi pembinaan dan pengawasan, pemerintah dapat menerapkan sanksi kepada penyelenggara pemerintahan daerah apabila ditemukan adanya penyimpangan dan pelanggaran oleh penyelenggara pemerintah daerah tersebut.

Fakta yang terjadi ketika pemerintah Propinsi Gorontalo dalam hal ini Inspektorat Propinsi melaksanakan fungsi pengawasanya untuk melakukan audit keuangan daerah, telah terjadi penolakan dari Pemerintah Kota Gorontalo untuk dilakukan audit keuangan daerah dengan alasan tidak jelas. Sehingga dinamika dalam penyelenggaraan pemerintahan dari sisi efektifitas pengawasan tidak berjalan dengan lancar. Keadaan ini telah mempengaruhi pada tidak berjalannya fungsi pengawasan terhadap penyelenggaraan pemerintahan.

Pengawasan dalam penyelenggaraan pemerintahan pada dasarnya mengarah pada terhindarnya kemungkinan adanya penyelewengan atau penyimpangan. Dinamika pemerintahan dalam konteks pengawasan dapat membantu pencapaian tujuan yang telah direncanakan. Selain itu juga sebagai instrumen pimpinan untuk mengevaluasi pelaksanaan kinerja, apakah telah sesuai dengan rencana yang telah dirumuskan. Hal ini sejalan dengan pendapat George R. Tery (2006:395) mengartikan pengawasan sebagai mendeterminasi apa yang telah dilaksanakan, maksudnya mengevaluasi prestasi kerja dan apabila perlu, menerapkan tindakan-tindakan korektif sehingga hasil pekerjaan sesuai dengan rencana yang telah ditetapkan.

\section{PENUTUP}

1. Disharmoni dalam koordinasi dan pengawasan dalam penyelenggaraan pemerintahan terjadi karena tidak tegasnya dukungan regulasi terkait dengan penyelenggaraan pemerintahan di daerah. Dan adanya nuansa negatif bahwa seakan kabupaten/kota terlepas dari provinsi.

2. Penelitian ini enyarankan, elit Pemerintah Propinsi maupun Kabupaten/Kota harus mampu mengubah mindset dalam menyelaraskan keseimbangan tanggungjawab, keduanya menjadi inisiator, motivator terhadap penyelengggaraan pemerintahan, dan menjadi fasilitator terbangunnya sinergitas yang strategis. Dan memperkuat kerjasama antar pemerintah 
daerah, sehingga antar pemerintah daerah baik kabupaten/kota maupun propinsi dapat saling mendukung pada pelaksanaan program kerja. Dan pada akhirnya dinamika penyelenggaraan pemerintahan dapat berjalan efektif dan efisien.

\section{DAFTAR PUSTAKA}

Amalia, Diamantina, 2010. Pengawasan Atas Penyelenggaraan Pemerintahan Daerah Untuk Menwujudkan Pemerintahan Daerah Yang Efektif dan Efisien. Jurnal MMH, 39 (1) Maret 2010.

Sukiansyah Murhani, 2008. Aspek Hukum Pengawasan Pemerintahan Daerah. Laksbang Mediatama, Yogyakarta

George R. Terry, 2006. Principles of Management. (Alih bahasa winardi), Alumni Bandung.

Handayaningrat. 1989. Manajemen Konflik. PT. Gramedia Pustaka Utama. Jakarta

Ndraha, Taliziduhu, 2003. Kybernology (Imu Pemerintahan Baru) 1. Rineka Cipta, Jakarta.

Siagian, Sondang P. 2011. Manajemen Sumber Daya Manusia. Jakarta : Bumi Aksara. 